\title{
Reduced embryonic survival in rainbow trout resulting from paternal exposure to the environmental estrogen $17 \alpha-$ ethynylestradiol during late sexual maturation
}

\author{
Kim H Brown, Irvin R Schultz ${ }^{1}$ and James J Nagler \\ Department of Biological Sciences and Center for Reproductive Biology, University of Idaho, Life Science Building \\ Room 252, PO Box 443051, Moscow, Idaho 83844-3051, USA and ${ }^{1}$ Battelle PNNL-Marine Science Laboratory, 1529 \\ West Sequim Bay Road, Sequim, Washington 98382, USA
}

Correspondence should be addressed to KH Brown; Email: khbrown@uidaho.edu

\begin{abstract}
Exposure of fishes to environmental estrogens is known to affect sexual development and spawning, but little information exists regarding effects on gametes. This study evaluated embryonic survival of offspring from male rainbow trout (Oncorhynchus mykiss) exposed to $17 \alpha$-ethynylestradiol $\left(\mathrm{EE}_{2}\right)$ using an in vitro fertilization protocol. Males were exposed at either 1800 or 6700 degree days ( $\left.{ }^{\circ} \mathrm{d}\right)$ (i.e. 161 or 587 days post-fertilization (dpf)) to test for effects on testes linked to reproductive ontogeny. At $1800^{\circ} \mathrm{d}$, fish were beginning testicular differentiation and were exposed to $109 \mathrm{ng} \mathrm{EE}_{2} / \mathrm{l}$ for 21 days. At $6700^{\circ} \mathrm{d}$, fish have testes

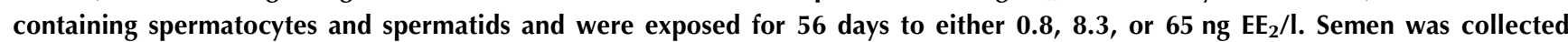
at full sexual maturity in each group and used to fertilize eggs pooled from several non-exposed females. Significant decreases in embryonic survival were observed only with the $6700^{\circ} \mathrm{d}$ exposure. In 0.8 and $8.3 \mathrm{ng} \mathrm{EE}_{2} / \mathrm{l}$ treatments, embryo survival was significantly reduced at $19 \mathrm{dpf}$ when compared with the control. In contrast, an immediate decrease in embryonic survival at 0.5 dpf was observed in the $65 \mathrm{ng} \mathrm{EE}_{2} / \mathrm{l}$ treatment. Blood samples collected at spawning from $6700^{\circ} \mathrm{d}$ exposed males revealed a significant decrease in 11-ketotestosterone and a significant increase in luteinizing hormone levels for the $65 \mathrm{ng} \mathrm{EE}_{2} / \mathrm{I}$ treatment when compared with the other treatment groups. Results indicate that sexually maturing male rainbow trout are susceptible to $\mathrm{EE}_{2}$ exposure with these fish exhibiting two possible mechanisms of reduced embryonic survival through sperm varying dependant on $\mathrm{EE}_{2}$ exposure concentrations experienced.
\end{abstract}

Reproduction (2007) 134 659-666

\section{Introduction}

Increasingly, detrimental reproductive effects in aquatic organisms due to environmental estrogens have been reported in both marine and freshwater ecosystems. These contaminants are widely distributed in aquatic environments and are identified through both direct chemical detection in surface waters as well as their known biological impacts in North America (Kolpin et al. 2002, Goksoyr 2006, Woodling et al. 2006), South America (Orrego et al. 2006), Europe (Jobling et al. 1998, Liney et al. 2005), and Asia (Hashimoto et al. 2000). The effects of environmental estrogens are primarily mediated by either their binding to or interference with estrogen receptors. This interaction results in direct or indirect obstruction of the endocrine system, thus inhibiting reproduction. Notable environmental estrogens include the synthetic human birth control pharmaceutical $17 \alpha$-ethynylestradiol $\left(\mathrm{EE}_{2}\right)$, the plasticizing agent bisphenol A, pesticides such as dichloro-diphenyl-trichloroethane (DDT), and the detergent metabolite nonylphenol, among others. Animals exposed to environmental estrogens have exhibited defects in sexual development, sexual behavior, and reproduction organ malformation (Blomqvist et al. 2006, Furuya et al. 2006, Ma \& Sassoon 2006). Besides these effects, fishes display abnormal intersexuality, reduced spawning success, reduced female fecundity, delayed male gonadal differentiation, reproductive duct malformation, and complete sex reversal (Jobling et al. 1998, 2003, Scholz \& Gutzeit 2000, Van den Belt et al. 2001, 2003, Balch et al. 2004, Nash et al. 2004, Versonnen \& Janssen 2004, Mills \& Chichester 2005, Campbell et al. 2006).

Environmental estrogens in aquatic environments come from both point and non-point sources, including agricultural runoff and pharmaceutical products passing through sewage treatment facilities (Ingerslev et al. 2003, 
Tashiro et al. 2003, Wang et al. 2004, Matthiessen et al. 2006). Sewage treatment plant effluent, the most frequent source of environmental estrogen contamination, can be directly released into adjacent surface waters. Documented reports of fishes in these waters with both physiological and developmental problems have been observed (Hashimoto et al. 2000, Jobling et al. 2003, Liney et al. 2005, Rempel et al. 2006). Sewage effluents may contain many environmental estrogens, but of particular concern is $\mathrm{EE}_{2}$. $\mathrm{EE}_{2}$ is extremely stable, released through most wastewater treatment facilities in an active form, and is highly potent when compared with native fish estrogens (Thorpe et al. 2003). It is widespread in surface waters with detectable concentrations ranging from 0.05 to $831 \mathrm{ng} \mathrm{EE}_{2} / \mathrm{I}$ (Ternes et al. 1999, Baronti et al. 2000, Huang \& Sedlak 2001, Kolpin et al. 2002).

Laboratory exposures of fishes to $\mathrm{EE}_{2}$ have documented numerous reproductive effects. A common experimental endpoint used is the assessment of reproductive success through natural spawning. Even though this endpoint shows that $\mathrm{EE}_{2}$ significantly affects adults, it does not contribute any insight into the mechanism of action regarding effects on gametes for the next generation. To establish an effect of $\mathrm{EE}_{2}$ on male gametes, Schultz et al. (2003) exposed sexually maturing male rainbow trout and utilized an in vitro fertilization approach with eggs from unexposed females to assess embryonic development. Using this method, they reported decreased embryonic survival with sperm from males exposed to concentrations as low as $10 \mathrm{ng}$ $\mathrm{EE}_{2} / \mathrm{l}$. Using in vitro fertilization trials when compared with natural spawning, this experimental design uniquely separated adult and gamete-specific $\mathrm{EE}_{2}$ effects, establishing an embryonic survival effect on offspring, not previously shown in fishes.

The decreased embryonic survival reported by Schultz et al. (2003) was assessed at 28 days post-fertilization (dpf), a time point when embryonic development in rainbow trout is nearly complete. While the presence of a significant effect on the male gamete is evident, questions regarding the actual timing of developmental interference remain unanswered. A range of possibilities exists to explain these results, from a failure at fertilization to some defect occurring during embryonic development due to influences of the paternal genome.
In addition, the timing of male $\mathrm{EE}_{2}$ exposure is also a variable requiring investigation. To determine the $\mathrm{EE}_{2}$-induced mechanism of action for reduced embryonic survival, the objectives of this study were: (1) to expose male parents at two different points during reproductive development, (2) to track embryonic development from fertilization onward in families derived from male rainbow trout exposed to different concentrations of $\mathrm{EE}_{2}$, and (3) to correlate embryo mortality patterns observed in offspring with reproductive hormones of the pituitary-gonad axis in the paternal parent.

\section{Results}

\section{Waterborne and blood plasma $E_{2}$ concentrations}

The nominal and measured water levels of $\mathrm{EE}_{2}$ during the 1800 and $6700^{\circ} \mathrm{d}$ experiments are shown in Table 1. Measured $\mathrm{EE}_{2}$ levels were within $60-100 \%$ of nominal values for all tested samples. Mean values of measured blood plasma concentrations of $\mathrm{EE}_{2}$ in males from the $6700^{\circ} \mathrm{d}$ experiment after 56 days were $0.0,0.55,2.83,36.56 \mathrm{ng} \mathrm{EE}_{2} / \mathrm{ml}$ in relation to nominal concentrations of $0,1,10$, and $100 \mathrm{ng} \mathrm{EE}_{2} / \mathrm{l}$ exposures respectively (Fig. 1).

\section{In vitro fertilization trials}

Sperm per milliliter of semen ranged from $1.16-8.93$ billion $/ \mathrm{ml}$ with means of $4.11,3.46,4.31$, and $4.99 \mathrm{billion} / \mathrm{ml}$ for the control, 0.8, 8.3, and $65 \mathrm{ng}$ $\mathrm{EE}_{2} / \mathrm{I}$ respectively in the $6700^{\circ} \mathrm{d}$ experiment. In the $1800^{\circ} \mathrm{d}$ experiment, sperm per milliliter of semen were 3.40 and 2.83 billion/ml for control and $\mathrm{EE}_{2}$ exposed treatments respectively. There were no significant differences in sperm concentrations between treatments in either experiment.

For the $6700^{\circ} \mathrm{d}$ experiment, one control group semen sample was inadvertently contaminated with water during collection, which prevented any fertilization in this sample. Embryonic development was therefore assessed on 39 out of 40 individuals sampled. Initial statistical analysis indicated that no tank effects were present for any developmental time

Table 1 Nominal and measured waterborne $17 \alpha$-ethynylestradiol $\left(\mathrm{EE}_{2}\right)$ concentrations ( $\left.\mathrm{ng} \mathrm{EE} / \mathrm{l}\right)$ in exposure tanks containing male rainbow trout that were 1800 degree days $\left({ }^{\circ} \mathrm{d}\right)$ or $6700^{\circ} \mathrm{d}$ in age.

\begin{tabular}{lccc}
\hline Experiment & Nominal exposure levels & Measured exposure levels (mean \pm s.D.) & Number of measurements $(n)$ \\
\hline $6700^{\circ} \mathrm{d}$ & 100 & $64.6 \pm 20$ & 11 \\
& 100 & $54.7 \pm 12$ & 11 \\
& 10 & $6.4 \pm 2.6$ & 5 \\
& 10 & $9.3 \pm 4.4$ & 4 \\
180.79 & 1 \\
& 1 & 0.84 & 4 \\
& 1 & $124.6 \pm 7.4$ & 4
\end{tabular}




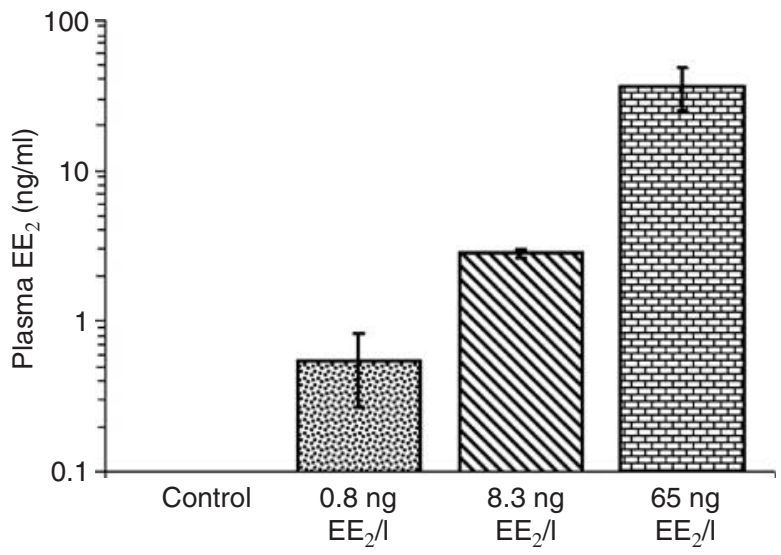

Figure 1 Blood plasma concentrations of $\mathrm{EE}_{2}$ in male rainbow trout after 56-day exposure to different $\mathrm{EE}_{2}$ levels. The bars represent a mean \pm s.D. $(n=3-7)$. Note that $y$-axis is on log scale.

points resulting in the ability to collapse the original statistical model to: $y_{\mathrm{ijk}}=\mu+\alpha_{\mathrm{i}}+e_{\mathrm{ij}}$, where $\alpha_{\mathrm{i}}$ represents treatment effects of $\mathrm{EE}_{2}$ and $e_{\mathrm{ij}}$ the random error. The collapsed model indicated that significant differences were present between all $\mathrm{EE}_{2}$ treatment groups and the control at the $19 \mathrm{dpf}$ developmental time point, eye pigmentation. Analyses of the three earlier developmental time points, 0.5, 2.5, and $9 \mathrm{dpf}$, revealed significant differences between the $65 \mathrm{ng}$ $\mathrm{EE}_{2} / \mathrm{l}$ treatment and the control, with no significant differences present between the 0.8 and $8.3 \mathrm{ng} \mathrm{EE}_{2} / \mathrm{l}$ treatments and the control (Fig. 2). No significant tank or treatment effects on embryonic survival at any developmental time point in the $1800^{\circ} \mathrm{d}$ experiment were detected (Fig. 3).

\section{Vitellogenin and hormone levels}

In the $6700^{\circ} \mathrm{d}$ experiment, plasma vitellogenin was non-detectable in the control group but detectable in

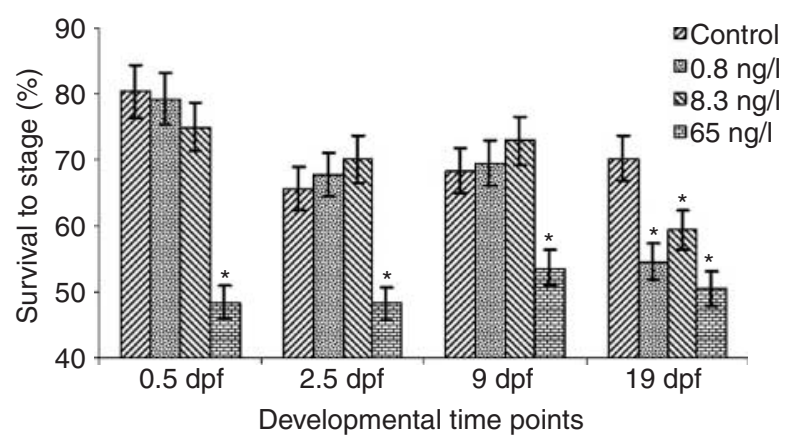

Figure 2 Embryonic survival through 19 days of development postfertilization for offspring of $6700^{\circ} \mathrm{d} \mathrm{EE}_{2}$ exposed male rainbow trout. The bars represent a mean \pm S.D; asterisks indicate significant differences between control and treatment group(s) at $P<0.05$.

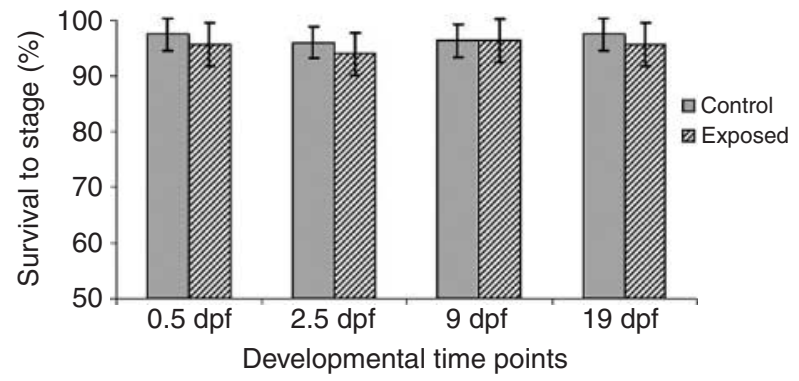

Figure 3 Embryonic survival through 19 days of development postfertilization for embryos of $1800^{\circ} \mathrm{d} \mathrm{EE}_{2}$ exposed male rainbow trout. Bars represent a mean \pm 1 s.D.

all fish exposed to $\mathrm{EE}_{2}$ and exhibited a positive doseresponse with increasing $\mathrm{EE}_{2}$ levels. Mean plasma vitellogenin levels were $0.027,62$, and $154 \mathrm{mg} / \mathrm{ml}$ for the $0.8,8.3$, and $65 \mathrm{ng} \mathrm{EE}_{2} / \mathrm{l}$ treatments respectively. Plasma 11-KT levels were similar in all treatment groups, with the exception of fish exposed to $65 \mathrm{ng}$ $\mathrm{EE}_{2} / \mathrm{l}$, where levels were significantly below other groups (Fig. 4). Plasma LH levels displayed a pattern in which a significant increase (Fig. 4) was observed in fish exposed to $65 \mathrm{ng} \mathrm{EE}_{2} / \mathrm{l}$ when compared with other treatment groups. FSH levels did not differ significantly among treatments with mean levels 0.718, 0.461, 0.782 , and $0.996 \mathrm{ng} / \mathrm{ml}$ for control, $0.8,8.3$, and $65 \mathrm{ng}$ $\mathrm{EE}_{2} / \mathrm{l}$ treatments respectively.
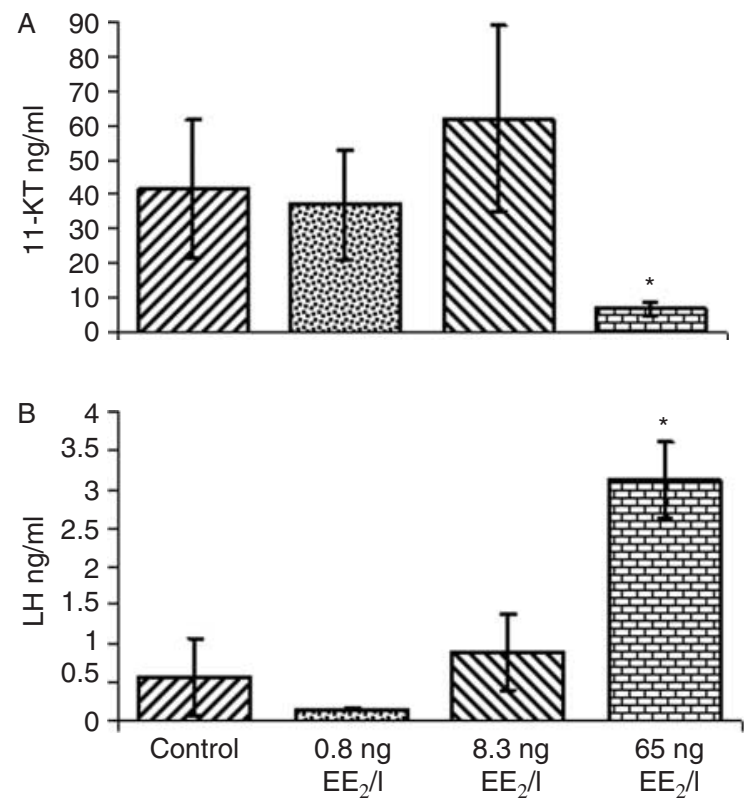

Figure 4 Blood plasma concentrations of (A) 11-ketotestosterone $(11-\mathrm{KT})$ and (B) luteinizing hormone $(\mathrm{LH})$ in $6700^{\circ} \mathrm{d}$ male rainbow trout after 56 days of exposure to different $\mathrm{EE}_{2}$ levels. The bars represent a mean \pm s.D. $(n=5)$; the asterisk indicates a significant difference from the control at $P>0.05$. 


\section{Discussion}

Effects of environmental estrogens have been noted in a wide range of aquatic species including frogs, salamanders, and fishes (Jones et al. 2000, Gye \& Kim 2005, Mosconi et al. 2005). Within fishes, the most commonly reported effect is induction of vitellogenin levels in male and/or juvenile animals (Rotchell \& Ostrander 2003). Although these types of studies provide useful information on environmental exposure, relatively few studies go beyond this basic analysis. Notable exceptions exist where studies have examined the role that environmental estrogens have on reproductive success. For example, using various fish model systems, environmental estrogen exposure has been shown to reduce spawning success due to interference with male reproductive behavior (Majewski et al. 2002, Hill \& Janz 2003, Martinovic et al. 2007). Schultz et al. (2003) used an in vitro fertilization approach designed to eliminate reproductive behavior effects, specifically analyzing the effect of $\mathrm{EE}_{2}$ on male gametes. This approach revealed the presence of significant sperm-specific decreased survival during early development resulting from $\mathrm{EE}_{2}$ exposure of male parents (Schultz et al. 2003). This reduced embryonic survival effect, affecting unexposed embryo development, represents a considerable challenge for determining a potential mechanism of action. Questions relating to how adult male parental exposure can be transmitted to developing embryos and whether ontogenetic time points of exposure are crucial must be addressed. Here, we illustrate that exposure to $\mathrm{EE}_{2}$ at $1800^{\circ} \mathrm{d}(161 \mathrm{dpf})$, prior to the initiation of spermatogenesis, has no effect on embryo survival. Either there is no effect of $\mathrm{EE}_{2}$ on these early germ cells or damaged germ cells are removed from the population before fish attain full sexual maturity. We also illustrate that $\mathrm{EE}_{2}$ exposure beginning at $6700^{\circ} \mathrm{d}(587 \mathrm{dpf})$, during late spermatogenesis/spermiation, causes significant reductions in embryonic survival. Therefore, during the final phases of reproductive development in male rainbow trout, testes appears uniquely vulnerable to $\mathrm{EE}_{2}$ at

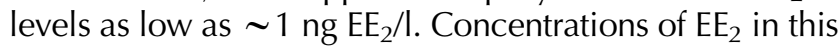
range are environmentally relevant and are therefore a concern for wild fish populations.

This study showed that exposure of sexually maturing male rainbow trout for 56 days to concentrations as low as $0.8 \mathrm{ng} \mathrm{EE}_{2} / \mathrm{l}$ produce significant reductions in survival to the eye pigmentation stage (19 dpf; Fig. 2). Although these results confirm reduced survival to the eye pigmentation stage previously observed (Schultz et al. 2003), the inclusion of additional developmental time points (early cleavage, blastula formation, and embryonic keel development) revealed two separate time points at which development and/or fertilization is affected. At $65 \mathrm{ng} \mathrm{EE}_{2} / \mathrm{l}$, either fertilization or embryonic development to first cleavage is affected. A determination regarding whether this effect is the result of development or fertilization cannot be made as no reliable method is currently available to specifically determine whether fertilization (at $0 \mathrm{dpf}$ ) has occurred. In contrast to the $65 \mathrm{ng} \mathrm{EE}_{2} / \mathrm{l}$ treatment, the 8.3 and $0.8 \mathrm{ng} \mathrm{EE}_{2} / \mathrm{l}$ doses did not exhibit significant development differences until much later, after embryonic keel formation (9 dpf). The timing of significant embryo mortality, early with $65 \mathrm{ng} \mathrm{EE}_{2} / \mathrm{l}$ exposed males and occurring later with 8.3 and $0.8 \mathrm{ng} \mathrm{EE}_{2} / \mathrm{l}$ exposed males, indicates the possibility of two mechanisms of action dependant on $\mathrm{EE}_{2}$ doses the parents receive during late sexual maturation.

Plasma analyses of three hormones in males from the $6700^{\circ} \mathrm{d}$ experiment revealed significant effects on 11-KT and $\mathrm{LH}$ for the $65 \mathrm{ng} \mathrm{EE}_{2} / \mathrm{l}$ treatment. $\mathrm{EE}_{2}$ does not appear to significantly affect these hormones in sexually maturing males at concentrations below $8.3 \mathrm{ng} \mathrm{EE}_{2} / \mathrm{l}$. In fishes, 11-KT is the major male androgen and has been reported to be crucial for spermatogenesis (Miura \& Miura 2003). Reduced levels of plasma 11-KT at the $65 \mathrm{ng} \mathrm{EE}_{2} / \mathrm{l}$ exposure are likely initiated through a direct action of $\mathrm{EE}_{2}$ on the testis. This reduction may result from a receptor-mediated shunting of hormone precursors from androgens to progestins (Kusakabe et al. 2006) or interference with estrogen receptors on Leydig cells (Bouma \& Nagler 2001) that produce 11-KT (Le Gac \& Loir 1988). Increased LH levels in the $65 \mathrm{ng} \mathrm{EE}_{2} / \mathrm{I}$ fish could be related to depressed 11-KT levels through a well-known negative feedback association between $\mathrm{LH}$ and $11-\mathrm{KT}$ at the pituitary or hypothalamus. This feedback system increases production of $\mathrm{LH}$ in male fishes when 11-KT levels are depressed (Yamaguchi et al. 2005). Alternatively, the increase in LH may be unrelated to $11-\mathrm{KT}$ and result from direct action of $\mathrm{EE}_{2}$ on the pituitary. Evidence exists for multiple estrogen response element-like sequences on the $\mathrm{LH}$ promoter of several fish species (Yaron et al. 2001, Melamed et al. 2006) and estrogens do interact with these elements, up-regulating the $L H$ gene (Liu et al. 1995). Therefore, $\mathrm{EE}_{2}$ in male rainbow trout could be binding to estrogen receptors and directly influencing $\mathrm{LH}$ transcription in the pituitary leading to elevated plasma levels.

Taken together, late sexual maturation exposure differences exhibited between high ( $\left.65 \mathrm{ng} \mathrm{EE}_{2} / \mathrm{l}\right)$ and low (8.3 and $0.8 \mathrm{ng} \mathrm{EE}_{2} / \mathrm{l}$ ) exposures from the $6700^{\circ} \mathrm{d}$ experiment in regard to both timing of embryo mortality and plasma hormone levels indicate the likelihood of two different mechanisms of action. Observed plasma vitellogenin and plasma $\mathrm{EE}_{2}$ levels support the fact that all treatment groups received $\mathrm{EE}_{2}$ exposures consistent with intended levels and that each had distinctly different levels of $\mathrm{EE}_{2}$. The high concentration (i.e. $65 \mathrm{ng} \mathrm{EE}_{2} / \mathrm{l}$ ) that produced alterations in plasma hormone levels (abnormally low 11-KT and high LH) may compromise the ability of some sperm to fertilize eggs properly. This potential problem with sperm fertilizing ability could account for the immediate, $0.5 \mathrm{dpf}$, difference in fertilization and/or early development. The combination of lower 11-KT and/or elevated LH may directly influence the final phase of 
spermatogenesis and spermiation in male rainbow trout. Not all sperm are affected since no evidence exists for complete reproductive failure, but a significant number may be afflicted. While an endocrine-mediated mechanism is possible for the high-dose treatment, no significant plasma hormone changes were present in fish from treatment groups at lower $\mathrm{EE}_{2}$ concentrations. To explain the observed decreased embryonic survival between 9 and $19 \mathrm{dpf}$ in the 0.8 and $8.3 \mathrm{ng} \mathrm{EE}_{2} / \mathrm{I}$ treatment groups, an alternative mechanism must be considered. In these two groups, a separate non-endocrine-mediated mechanism could be present. Since embryonic development proceeded normally through $9 \mathrm{dpf}$, some genomic defect of the sperm DNA is proposed. This hypothesis is consistent with other studies in rainbow trout in which sperm DNA was intentionally damaged (Patton et al. 2007). Two lines of evidence support this: no differences were observed between treatment groups and controls at 0.5 or $9 \mathrm{dpf}$; and this and previous studies have revealed no variation in sperm number, morphology, or swimming ability following $\mathrm{EE}_{2}$ exposure in sexually mature male rainbow trout (Schultz et al. 2003).

Sperm DNA damage could be occurring through two possible mechanisms: aberrant DNA methylation or meiotic interference during spermatogenesis. Exposures of environmental toxicants have been shown to reduce fertility in rats through a process of aberrant DNA methylation of the germ line (Anway et al. 2005). These incorrect DNA methylation patterns were shown to result in heritable defects affecting progeny fertility over multiple generations. Using medaka, Contractor et al. (2004) illustrated that $\mathrm{EE}_{2}$ is capable of inducing methylation changes to the estrogen receptor and aromatase genes, indicating the possibility that $\mathrm{EE}_{2}$-induced DNA methylation changes may be responsible for reduced embryo survival in our study. Alternatively, meiosis during spermatogenesis may be affected. The fact that treatment of male rainbow trout at $1800^{\circ} \mathrm{d}$, prior to the initiation of spermatogenesis (i.e. meiosis), did not result in reduced fertility/development supports this hypothesis as well as research in other vertebrates. Bisphenol-A, a less potent environmental estrogen than $\mathrm{EE}_{2}$, has been shown to affect meiosis in female mice resulting in the production of aneuploid gametes (Hunt et al. 2003). The production of such gametes would result in decreased survival of embryos and could account for the observed reduced survival after $9 \mathrm{dpf}$. Since both mechanisms are possible reasons for reduced embryonic survival, further research is necessary to determine exactly how $\mathrm{EE}_{2}$ exposure of male parents actually reduces embryonic survival of offspring.

\section{Materials and Methods}

\section{Research animals and facilities}

Fish used in experiments were maintained according to guidelines established by the Institutional Animal Care and Use
Committees of Battelle Pacific Northwest National Laboratory, Washington State University (WSU) and the University of Idaho (UI). Male isogenic rainbow trout were produced at the WSU research fish hatchery by fertilizing eggs from a homozygous clonal Oregon State University (OSU) strain female rainbow trout with sperm from a homozygous clonal Arlee strain male rainbow trout. Clonal females and males were originally produced through gynogenesis and androgenesis respectively and are maintained at the WSU research fish hatchery (Parsons \& Thorgaard 1985, Young et al. 1996, Young et al. 1998). Offspring resulting from the OSU $\times$ Arlee cross, termed clonal hybrids, are genetically identical, greatly reducing levels of phenotypic variation within experimental groups. After fertilization, embryos were placed in a Heath-style fish egg incubator (MariSource, Milton, WA, USA) at $10.5{ }^{\circ} \mathrm{C}$ until yolk sac absorption and then transported to Battelle Marine Research Laboratory (MRL) in Sequim, WA, USA. Upon arrival at MRL, fish were 530 degree days $\left({ }^{\circ} \mathrm{d}=\right.$ water temperature in ${ }^{\circ} \mathrm{C} \times$ number of days) in age. Before and after chemical exposures, trout were housed in groups of 25-75 fish in circular fiberglass tanks ranging in size from 100, 370, or 1400 I depending on fish size. All tanks were maintained with a single-pass flow-through freshwater system. The MRL uses artesian well water (well depth $=134 \mathrm{~m}$ ), pre-aerated before reaching holding tanks at a minimum flow rate of $1 \mathrm{l} / \mathrm{min}$ per $\mathrm{kg}$ fish. Water quality parameters were routinely measured in holding and treatment tanks, averaging $11.5^{\circ} \mathrm{C},>9 \mathrm{mg} / \mathrm{l}$ dissolved oxygen, $\mathrm{pH} 7.9$, total alkalinity $200 \mathrm{mg} / \mathrm{l}\left(\mathrm{as} \mathrm{CaCO}_{3}\right.$ ), ammonia $<0.05 \mathrm{mg} / \mathrm{l}$, and nitrate-nitrite $<0.01 \mathrm{mg} / \mathrm{l}$. Fish were initially fed mashed feed several times a day using automatic feeders and transitioned to soft-moist, pelleted feed of various sizes thereafter (Bio-Oregon Inc., Warrenton, OR, USA). All holding and exposure tanks were maintained under simulated natural photoperiod with graded off- and on-controls.

\section{Exposure trials and sample collections}

The $\mathrm{EE}_{2}$ exposures were performed with trout at two different reproductive ontogenetic time points, 1800 and $6700^{\circ} \mathrm{d}$. These time points were chosen because they represent initial testicular differentiation from the undifferentiated gonad with the presence of spermatogonia $\left(1800^{\circ} \mathrm{d}\right.$; Takashima et al. 1980) and an actively meiotic, mid-spermatogenetic time point with spermatocytes and spermatids predominating the gonad prior to final sexual maturation $\left(6700^{\circ} \mathrm{d}\right.$; Kusakabe et al. 2006) in rainbow trout. Degree day exposure times were calculated from 161 and 587 (dpf) using the rearing temperatures in our experimental holding facilities with individual animal weights of $\sim 10$ and $750 \mathrm{~g}$ respectively. For exposure treatments, $\mathrm{EE}_{2}$ was delivered using a flow-through system in 370 I tanks from a concentrated stock solution of $\mathrm{EE}_{2}$ prepared in methanol:water $(60 \% \mathrm{v} / \mathrm{v})$ that was slowly added to exposure tanks with a peristaltic pump flow rate of $0.07 \mathrm{ml} / \mathrm{min}$ (equals $0.0008 \%$ methanol in tanks). Control tanks had only methanol added. For the $1800^{\circ} \mathrm{d}$ experiment, 60 male rainbow trout were randomly divided into two tank replicates and exposed to a nominal concentration of $100 \mathrm{ng} \mathrm{EE}_{2} / \mathrm{l}$ or methanol only (solvent control) for 21 days. Following exposures, individuals were transferred to fresh water and allowed to progress 
normally to sexual maturation when semen samples were collected from five individuals per replicate for a total of ten control and ten exposed males as described below. At $6700^{\circ} \mathrm{d}$, 80 male rainbow trout were randomly divided into eight groups of ten fish per tank with two tank replicates per treatment. Individuals were continuously exposed to three treatment levels of $\mathrm{EE}_{2}$ or methanol only (solvent control). Nominal concentration levels of 1, 10, and $100 \mathrm{ng} \mathrm{EE}_{2} / \mathrm{l}$ were employed. Water and stock solution in-flow rates for all tanks in each treatment were monitored daily. Measured $\mathrm{EE}_{2}$ concentrations were monitored every 7 days for the $1800^{\circ} \mathrm{d}$ experiment and every 7-14 days for the 10 and $100 \mathrm{ng} \mathrm{EE}_{2} / \mathrm{I}$ treatments and once for the $1 \mathrm{ng} \mathrm{EE}_{2} / \mathrm{l}$ treatment for the $6700^{\circ} \mathrm{d}$ experiment. The $6700^{\circ} \mathrm{d}$ experiment continued for 56 days after which five randomly selected individuals per tank and ten fish per treatment (40 fish total) were sampled. All fish were anesthetized using buffered $0.25 \mathrm{~g} / \mathrm{l}$ MS-222 (Argent, Redmond, WA, USA). Individual semen samples from each anesthetized fish were collected by manual expression directly into sterile plastic bags (Whirl-Pak, NASCO, Fort Atkinson, WI, USA) and placed on ice.

For the $6700^{\circ} \mathrm{d}$ experiment, following semen collection, blood samples were obtained from anesthetized fish using $5 \mathrm{ml}$ heparinized syringes with 21 gauge needles. Blood was drawn from the caudal vein, inverted ten times ensuring proper mixture of heparin, and placed on ice prior to plasma separation by centrifugation. To avoid hemolysis, blood samples remained on ice no longer than 10 min before centrifugation. Plasma was removed after centrifugation and transferred to $1.5 \mathrm{ml}$ microcentrifuge tubes before being placed at $-20{ }^{\circ} \mathrm{C}$ for storage. After blood collection, fish were euthanized and total weight was obtained.

\section{Determination of $\mathrm{EE}_{2}$ in water and plasma}

Water and plasma samples were analyzed for $\mathrm{EE}_{2}$ by GC-MS. Water samples (0.05-1 I in volume) were fortified with $\mathrm{NaCl}$ $(5 \% \mathrm{w} / \mathrm{v})$ and extracted with $75 \mathrm{ml}$ methyl-tert-butyl-ether (MTBE) per $1 \mathrm{I}$ sample. Plasma samples $(0.2 \mathrm{ml})$ were mixed with an equal volume of saturated aqueous $\mathrm{NaCl}$ solution and extracted with $1 \mathrm{ml}$ MTBE. The MTBE fractions were removed, evaporated under $\mathrm{N}_{2}$, and subsequently derivatized with $\mathrm{N}$-methyl-N-trimethylsilyl-trifluoroacetamide essentially as described in Schultz et al. (2001) except that ${ }^{3} \mathrm{~d}$-estradiol was added as an internal standard in extractions. The GC-MS was operated in selected ion monitoring mode with $\mathrm{m} / \mathrm{z} 419$ and $\mathrm{m} / \mathrm{z} 425$ ions used for ${ }^{3} \mathrm{~d}$-estradiol and $\mathrm{EE}_{2}$ quantification. $\mathrm{EE}_{2}$ recovery from fortified water standards and blood plasma always exceeded $95 \%$.

\section{In vitro fertilization protocol}

Semen from both the 1800 and $6700^{\circ} \mathrm{d}$ experiments were transported to the UI on ice. For in vitro fertilization trials, both experiments were fertilized using the same batch of pooled, outbred rainbow trout eggs purchased from TroutLodge Inc. (Sumner, WA, USA). Sperm number was quantified using a hemocytometer to determine the number of sperm per microliter of semen. For in vitro fertilization, semen was diluted using immobilizing medium $(80 \mathrm{mM} \mathrm{NaCl}, 40 \mathrm{mM}$ $\mathrm{KCl}, 0.1 \mathrm{mM} \mathrm{CaCl}, 30 \mathrm{mM}$ Tris- $\mathrm{HCl}$, pH 9.2, Cosson et al. 1999) and added to $\sim 150$ unfertilized rainbow trout eggs to produce a sperm:egg ratio of 300 000:1. After the gametes were combined, a small amount $(10 \mathrm{ml})$ of chilled, sperm activation medium $(125 \mathrm{mM} \mathrm{NaCl}, 0.1 \mathrm{mM} \mathrm{CaCl}, 30 \mathrm{mM}$ Tris- $\mathrm{HCl}, \mathrm{pH} 9.2$, Cosson et al. 1999) was added to initiate sperm motility. The gamete mixture was then gently swirled and allowed to stand for 5 min completing fertilization. After $5 \mathrm{~min}$, fertilized eggs were rinsed using cold dechlorinated tap water thrice and placed in Heath incubators. Following fertilization, four developmental time points were assessed: $0.5,2.5,9$, and $19 \mathrm{dpf}$, representing early cleavage, raised blastula, embryonic keel, and eye pigmentation stages respectively (Ballard 1973). At each of the first three time points, 25 randomly selected eggs were removed, fixed in Stockard's solution (Ballard 1973), and developmental success gauged as described in Stoddard et al. (2005). The last time point (eye pigmentation) was visually assessed on remaining live embryos.

\section{Plasma vitellogenin and hormone analysis}

Plasma vitellogenin levels were determined in samples (freshly thawed on crushed ice) using a rainbow trout vitellogenin ELISA kit (Cayman Chemical, Ann Arbor, MI, USA). Samples were prepared and analyzed as described by the kit assay procedure. The androgen 11-ketotestosterone (11-KT) was determined in freshly thawed plasma samples using an 11-KT ELISA as described by Cuisset et al. (1994). The gonadotropins, follicle-stimulating hormone ( $\mathrm{FSH})$, and luteinizing hormone (LH) were determined using salmonid RIAs as described by Swanson et al. (1989).

\section{Statistical analysis}

Embryonic development data were statistical analyzed using a completely randomized design. Fertilization percentages were analyzed after performing an arcsine transformation to normalize values, while plasma vitellogenin, plasma $\mathrm{EE}_{2}$, and hormone data were analyzed without transformation. The linear model for all analyses was $y_{\mathrm{ijk}}=\mu+\alpha_{\mathrm{i}}+\beta_{\mathrm{j}}+(\alpha \beta)_{\mathrm{ij}}+e_{\mathrm{ijk}}$, where $\alpha_{\mathrm{i}}$ represents $\mathrm{EE}_{2}$ treatment effects, $\beta_{\mathrm{j}}$ tank effects, $(\alpha \beta)_{\mathrm{ij}}$ interaction effects, and $e_{i j k}$ the random error. ANOVA was performed to determine whether significant differences were present between treatments using PROC GLM in SAS/STAT (SAS Institute, Cary, NC, USA). When indicated by ANOVA, Fisher's protected LSD was performed to determine which treatments differed significantly from one another.

\section{Acknowledgements}

The authors would like to thank Mr Steve Patton and Dr Tim Cavileer for their assistance with sample collection, and Dr Sean Lema and Dr Penny Swanson for performing plasma hormone analyses. This research was supported by the National Institute of Environmental Health Sciences grant ES012446. The authors 
declare that there is no conflict of interest that would prejudice the impartiality of this scientific work.

\section{References}

Anway M, Cupp AS, Uzumcu M \& Skinner MK 2005 Epigenetic transgenerational actions of endocrine disruptors and male fertility. Science 308 1466-1469.

Balch GC, Mackenzie CA \& Metcalfe CD 2004 Alterations to gonadal development and reproductive success in Japanese medaka (Oryzias latipes) exposed to 17 alpha-ethinylestradiol. Environmental Toxicology and Chemistry 23 782-791.

Ballard WW 1973 Normal embryonic stages for salmonid fishes, based on Salmo gairdneri Richardson and Salvelinus fontinalis (Mitchell). Journal of Experimental Zoology 184 7-26.

Baronti C, Curini R, D'Ascenzo G, Di Corcia A, Gentili A \& Samperi R 2000 Monitoring natural and synthetic estrogens at activated sludge sewage treatment plants and in a receiving river water. Environmental Science \& Technology 34 5059-5066.

Van den Belt K, Verheyen R \& Witters H 2001 Reproductive effects of ethynylestradiol and 4t-octylphenol on the zebrafish (Danio rerio). Archives of Environmental Contamination and Toxicology 41 458-467.

Van den Belt K, Verheyen R \& Witters H 2003 Effects of 17 alphaethynylestradiol in a partial life-cycle test with zebrafish (Danio rerio): effects on growth, gonads and female reproductive success. Science of the Total Environment 309 127-137.

Blomqvist A, Berg C, Holm L, Brandt I, Ridderstrale Y \& Brunstrom B 2006 Defective reproductive organ morphology and function in domestic rooster embryonically exposed to $o, p^{\prime}$-DDT or ethynylestradiol. Biology of Reproduction 74 481-486.

Bouma J \& Nagler JJ 2001 Estrogen receptor-a protein localization in the testis of the rainbow trout (Oncorhynchus mykiss) during different stages of the reproductive cycle. Biology of Reproduction 65 60-65.

Campbell PM, Fernandez MP, Royston S, Smith JL, van Poppelen P, Ikonomou MG \& Devlin RH 2006 Male coho salmon (Oncorhynchus kisutch) exposed to a time-course of urban sewage effluent exhibit a sporadic low incidence of sex reversal and intersex. Water Quality Research Journal of Canada 41 235-243.

Contractor RG, Foran CM, Li SF \& Willett KL 2004 Evidence of gender- and tissue-specific promoter methylation and the potential for ethinylestradiol-induced changes in japanese medaka (Oryzias latipes) estrogen receptor and aromatase genes. Journal of Toxicology and Environmental Health. Part A 67 1-22.

Cosson J, Billard R, Cibert C, Dreanno C \& Suquet M 1999 lonic factors regulating the motility of fish sperm. In The Male Gamete: From Basic Science to Clinical Applications, pp 161-186. Ed. C Gagnon. Vienna, IL: Cache River Press.

Cuisset B, Pradelles P, Kime DE, Kuhn ER, Babin P \& Le Menn F 1994 Enzyme immunoassay for 11-ketotestosterone using acetylcholinesterase as label: application to the measurement of 11-ketotestosterone in plasma of Siberian sturgeon. Comparative Biochemistry and Physiology. Part C, Toxicology \& Pharmacology 108 229-241.

Furuya M, Adachi K, Kuwahara S, Ogawa K \& Tsukamoto Y 2006 Inhibition of male chick phenotypes and spermatogenesis by Bisphenol-A. Life Sciences 78 1767-1776.

Le Gac F \& Loir M 1988 Control of testis function in fish: in vitro studies of gonadotropic regulation in the trout (Salmo gairdneri). Reproduction, Nutrition, Development 28 1031-1046.

Goksoyr A 2006 Endocrine disruptors in the marine environment: mechanisms of toxicity and their influence on reproductive processes in fish. Journal of Toxicology and Environmental Health, Part A: Current Issues 69 175-184.

Gye MC \& Kim DH 2005 Bisphenol A induces hepatic vitellogenin mRNA in male Bombina orientalis. Bulletin of Environmental Contamination and Toxicology 75 1-6.

Hashimoto S, Bessho H, Hara A, Nakamura M, Iguchi T \& Fujita K 2000 Elevated serum vitellogenin levels and gonadal abnormalities in wild male flounder (Pleuronectes yokohamae) from Tokoyo Bay, Japan. Marine Environmental Research 49 37-53.
Huang CH \& Sedlak DL 2001 Analysis of estrogenic hormones in municipal wastewater effluent and surface water using enzyme-linked immunosorbent assay and gas chromatography/tandem mass spectrometry. Environmental Toxicology and Chemistry 20 133-139.

Hill RL Jr \& Janz DM 2003 Developmental extrogenic exposure in zebrafish (Danio rerio): I. effects on sex ratio and breeding success. Aquatic Toxicology 63 417-429.

Hunt PA, Koehler KE, Susiarjo M, Hodges CA, llagan A, Voigt RC, Thomas S, Thomas BF \& Hassold TJ 2003 Bisphenol a exposure causes meiotic aneuploidy in the female mouse. Current Biology 13 546-553.

Ingerslev F, Vaclavik E \& Halling-Sorensen B 2003 Pharmaceuticals and personal care products: a source of endocrine disruption in the environment? Pure and Applied Chemistry 75 1881-1893.

Jobling S, Nolan M, Tyler CR, Brighty G \& Sumpter JP 1998 Widespread sexual disruption in wild fish. Environmental Science \& Technology 32 2498-2506.

Jobling S, Casey D, Rodgers-Gray T, Oehlmann J, Schulte-Oehlmann U, Pawlowski S, Baunbeck T, Turner AP \& Tyler CR 2003 Comparative response of mollusks and fish to environmental estrogens and an estrogenic effluent. Aquatic Toxicology 65 205-220.

Jones PD, De Coen WM, Tremblay L \& Giesy JP 2000 Vitellogenin as a biomarker for environmental estrogens. Water Science and Technology: A Journal of the International Association on Water Pollution Research 42 $1-14$.

Kolpin DW, Furlong ET, Meyer MT, Thurman EM, Zaugg SD, Barber LB \& Buxton HT 2002 Pharmaceuticals, hormones, and other organic wastewater contaminants in US streams, 1999-2000: a national reconnaissance. Environmental Science \& Technology 36 1202-1211.

Kusakabe M, Nakamura I, Evans J, Swanson P \& Young G 2006 Changes in mRNAs encoding steroidogenic acute regulatory protein, steroidogenic enzymes and receptors for gonadotropins during spermatogenesis in rainbow trout testes. Journal of Endocrinology 189 541-554.

Liney KE, Jobling S, Shears JA, Simpson P \& Tyler CR 2005 Assessing the sensitivity of different life stages for sexual disruption in Roach (Rutilus rutilus) exposed to effluents from wastewater treatment works. Environmental Health Perspectives 113 1299-1307.

Liu D, Xiong F \& Hew CL 1995 Functional analysis of estrogen-responsive elements in chinook salmon (Oncorhynchus tschawytscha) gonadotropin II beta subunit gene. Endocrinology 136 3486-3493.

Ma RS \& Sassoon DA 2006 PCBs exert an estrogenic effect through repression of the Wnt7a signaling pathway in the female reproductive tract. Environmental Health Perspectives 114 898-904.

Majewski AR, Blanchfield PJ, Palace VP \& Wautier K 2002 Waterborne 17(alpha-ethynylestradiol affects aggressive behaviour of male fathead minnows (Pimephales promelas) under artificial spawning conditions. Water Quality Research Journal of Canada 37 697-710.

Martinovic D, Hogarth WT, Jones RE \& Sorensen PW 2007 Environmental estrogens suppress hormones, behavior, and reproductive fitness in male fathead minnows. Environmental Toxicology and Chemistry 26 271-278.

Matthiessen P, Arnold D, Johnson AC, Pepper TJ, Pottinger TG \& Pullman KGT 2006 Contamination of headwater streams in the United Kingdom by oestrogenic hormones from livestock farms. Science of the Total Environment 367 616-630.

Melamed P, Zhu Y, Tan SH, Xie M \& Koh M 2006 Gonadotropin-releasing hormone activation of c-jun, but not early growth response factor-1, stimulates transcription of a luteinizing hormone beta-subunit gene. Endocrinology 147 3598-3605.

Mills LJ \& Chichester C 2005 Review of evidence: are endocrine-disrupting chemicals in the aquatic environment impacting fish populations? Science of the Total Environment 343 1-34.

Miura T \& Miura CI 2003 Molecular control mechanisms of fish spermatogenesis. Fish Physiology and Biochemistry 28 181-186.

Mosconi G, Di Rosa I, Bucci S, Morosi L, Franzoli MF, Polzonetti-Magni AM \& Pascolini R 2005 Plasma sex steroid and thyroid hormones profile in male water frogs of the Rana esculenta complex from agricultural and pristine areas. General and Comparative Endocrinology 142 318-324.

Nash JP, Kime DE, Van der Ven LTM, Wester PW, Brion F, Maack G, Stahlschmidt-Allner P \& Tyler CR 2004 Long-term exposure to environmental concentrations of the pharmaceutical ethynylestradiol causes reproductive failure in fish. Environmental Health Perspectives 112 1725-1733. 
Orrego R, Burgos A, Moraga-Cid G, Inzunza B, Gonzalez M, Valenzuela A, Barra R \& Gavilan JE 2006 Effects of pulp and paper mill discharges on caged rainbow trout (Oncorhynchus mykiss): Biomarker responses along a pollution gradient in the Biobio River, Chile. Environmental Toxicology and Chemistry 25 2280-2287.

Parsons JE \& Thorgaard GH 1985 Production of androgenic diploid rainbow trout. Journal of Heredity 76 177-181.

Patton SJ, Kane SL, Wheeler PA \& Thorgaard GH 2007 Maternal and paternal influence on early embryonic survival of androgenetic rainbow trout (Oncorhynchus mykiss): implications for measuring egg quality. Aquaculture $26326-34$.

Rempel MA, Reyes J, Steinert S, Hwang W, Armstrong J, Sakamoto K, Kelley K \& Schlenk D 2006 Evaluation of relationships between reproductive metrics, gender and vitellogenin expression in demersal flatfish collected near the municipal wastewater outfall of Orange County, California, USA. Aquatic Toxicology 77 241-249.

Rotchell JM \& Ostrander GK 2003 Molecular markers of endocrine disruption in aquatic organisms. Journal of Toxicology and Environmental Health, Part B: Critical Reviews 6 453-495.

Scholz S \& Gutzeit HO 2000 17-alpha-ethinylestradiol affects reproduction, sexual differentiation and aromatase gene expression of the medaka (Oryzias latipes). Aquatic Toxicology 50 363-373.

Schultz IR, Orner G, Merdink JL \& Skillman A 2001 Dose-response relationships and pharmacokinetics of vitellogenin in rainbow trout after intravascular administration of 17 alpha-ethynylestradiol. Aquatic Toxicology 51 305-318.

Schultz IR, Skillman A, Nicolas J, Cyr DG \& Nagler JJ 2003 Short-term exposure to $17 \alpha$-ethynylestradiol decreases the fertility of sexually maturing male rainbow trout (Oncorhynchus mykiss). Environmental Toxicology and Chemistry 22 1272-1280.

Stoddard JW, Parsons JE \& Nagler JJ 2005 Early onset of embryonic mortality in sub-fertile families of rainbow trout (Oncorhynchus mykiss). Reproduction, Fertility and Development 17 785-790.

Swanson P, Bernard M, Nozaki M, Suzuki K, Kawauchi H \& Dickhoff WW 1989 Gonadotropins I and II in juvenile coho salmon. Fish Physiology and Biochemistry 7 169-176.

Takashima F, Patino R \& Nomura M 1980 Histological studies on the sex differentiation in rainbow trout. Bulletin of the Japanese Society of Scientific Fisheries 46 1317-1322.

Tashiro Y, Takemura A, Fujii H, Takahira K \& Nakanishi Y 2003 Livestock wastes as a source of estrogens and their effects on wildlife of Manko tidal flat, Okinawa. Marine Pollution Bulletin 47 143-147.
Ternes TA, Stumpf M, Mueller J, Haberer K, Wilken RD \& Servos M 1999 Behavior and occurrence of estrogens in municipal sewage treatment plants - I. Investigations in Germany, Canada and Brazil. Science of the Total Environment 225 81-90.

Thorpe KL, Cummings RI, Hutchinson TH, Scholze M, Brighty G, Sumpter JP \& Tyler CR 2003 Relaive potencies and combination effects of steroidal estrogens in fish. Environmental Science \& Technology 37 $1142-1149$.

Versonnen BJ \& Janssen CR 2004 Xenoextrogenic effects of ethinylestradiol in zebrafish (Danio rerio). Environmental Toxicology 19 198-206.

Wang HL, Magesan GN \& Bolan NS 2004 An overview of the environmental effects of land application of farm effluents. New Zealand Journal of Agricultural Research 47 389-403.

Woodling JD, Lopez EM, Maldonado TA, Norris DO \& Vajda AM 2006 Intersex and other reproductive disruption of fish in wastewater effluent dominated Colorado streams. Comparative Biochemistry and Physiology. Part C, Toxicology \& Pharmacology 144 10-15.

Yamaguchi S, Gen K, Okuzawa K, Kumakura N, Matsuyama M \& Kagawa H 2005 Effects of 11-ketotestosterone and gonadotropin-releasing hormone on follicle-stimulating hormone and luteinizing hormone gene expression in castrated and sham-operated male red seabream Pogrus major. Fisheries Science 71 1049-1058.

Yaron Z, Gur G, Melamed P, Rosenfeld H, Levavi-Sivan B \& Elizur A 2001 Regulation of gonadotropin subunit genes in tilapia. Comparative Biochemistry and Physiology. Part B, Biochemistry and Molecular Biology 129 498-502.

Young WP, Wheeler PA, Fields RD \& Thorgaard GH 1996 DNA fingerprinting confirms isogenecity of androgenetically derived rainbow trout lines. Journal of Heredity 87 77-81.

Young WP, Wheeler PA, Coryell VH, Keim P \& Thorgaard GH 1998 A detailed linkage map of rainbow trout produced using doubled haploids. Genetics 148 839-850.

Received 13 April 2007

First decision 21 May 2007

Accepted 2 August 2007 